\title{
Factors Influencing Faculty Satisfaction with Asynchronous Teaching and Learning in the SUNY Learning Network
}

\author{
Eric Fredericksen, Alexandra Pickett, Peter Shea \\ State University of New York \\ William Pelz \\ Herkimer County Community College \\ Karen Swan \\ University of Albany
}

\begin{abstract}
"...100\% of faculty reported that they were either satisfied or very satisfied with the SUNY Learning Network."

Spring 1999 SLN Faculty Satisfaction Survey
\end{abstract}

The State University of New York (SUNY) Learning Network (SLN) is the on-line instructional program created for the 64 colleges and nearly 400,000 students of SUNY. The foundation of the program is freedom from schedule and location constraints for our faculty and students. The primary goals of the SLN are to bring SUNY's diverse and high-quality instructional programs within the reach of learners everywhere, and to be the best provider of asynchronous instruction for learners in New York State and beyond. We believe that these goals cannot be achieved unless faculty receives appropriate support. This paper will examine factors that have contributed to the high level of faculty satisfaction we have achieved in the SLN. The analysis will be done on several levels. This first section will look at the SLN at a program-wide level and will provide information regarding the systemic implementation of our asynchronous learning environment.

The second section examines issues that contribute to on-line teaching satisfaction from a facultydevelopment and course-design perspective. This section will present the evolution of the four-stage faculty development process and a seven-step course design process that was developed by SLN and comment on lessons learned.

The third section presents results from the SLN Faculty Satisfaction Survey conducted in spring 1999. This section examines factors from a quantitative analysis that significantly contributes to faculty satisfaction with on-line teaching and offers recommendations for course and program design based on these factors.

The fourth section examines faculty satisfaction at the level of individual institutions with examples from specific courses. This section will introduce the reader to local implementation of SLN courses at two 
college programs in the SUNY system: the Department of Educational Theory and Practice at the University at Albany (UA), and the Internet Academy (IA) of Herkimer County Community College (HCCC). These case studies present and examine important evidence of faculty satisfaction from a single-institution and individual-faculty perspective.

\section{INTRODUCTION}

With generous support from the Alfred P. Sloan Foundation—combined with enthusiasm and resources from SUNY System Administration and participating campuses - the SLN has successfully met the challenges of the initial developmental phases that focused on proof of concept and expansion/scalability. The annual growth in courses, from eight in 1995-96 to 1,000 in 1999-2000, and annual growth in enrollment, from 119 in 1995-96 to more than 10,000 in 1999-2000, illustrates that the project has far exceeded the original projections.

The SLN started as a regional project in the Mid-Hudson Valley involving eight SUNY campuses. At that time, the development and delivery of asynchronous courses was a new activity for SUNY campuses and faculty. The first courses were offered in the 1995-96 academic year.

Successful experiences led to an expanded vision and goals for the SLN and the scope and objectives of the project have grown substantially. Whereas we originally developed courses at the third- and fourth-year levels - that were offered by two of our institutions, we are now offering courses at all undergraduate levels, as well as the graduate level, and 42 of our institutions are involved. Our initial developmental phase focused on proof of concept within the SUNY system. This was followed by a phase that focused on proof of scalability that achieved significant growth in course offerings and student enrollments. SUNY's efforts continue to evolve the SLN from a project status to a fully integrated virtual learning component responsive to the needs of learners in the new millennium. Ultimately, the SLN will represent the entire SUNY through the creation of one virtual campus that will be open seven days a week, 24 hours a day to students across the globe.

The SLN primary mission is to bring SUNY's high quality instructional programs within reach of learners anywhere. Another objective has been to take an efficient approach in supporting the SUNY campuses. Rather than each campus reinventing the wheel, SLN has developed and implemented the appropriate operational services and support yielding both cost savings as well as the sharing of experience from one campus to another.

SLN has traditionally assisted campuses in conducting individual course evaluations. Additionally, the SLN office conducted two program-level student surveys and one faculty survey during the 1998-99 academic year. The faculty study focused on appraising the satisfaction of faculty with SLN and determining what factors contribute to faculty satisfaction. The results of this survey are presented in this paper.

SLN strives to provide the appropriate high quality services and support to faculty so that they may provide a rich learning environment for their students and have high quality teaching experiences. SLN has taken a lot of pride in working with some of the outstanding SUNY faculty. The success of SLN is inextricably related to the number of faculty who emerge from the project as both competent and enthusiastic regarding asynchronous course delivery.

\section{BACKGROUND}

Prior to the SLN program, many SUNY campuses were starting to experiment with asynchronous components to complement their classroom-based courses. In addition, some SUNY campuses were taking regional approaches to utilizing synchronous two-way videoconference and some satellite broadcast forms of distance learning courses. SLN has been unique in SUNY in that it has been a unifying effort for all SUNY campuses to participate in the same single-system program for ALN. 
SLN is not a replacement for the classroom - it is another choice for students and is, therefore, open to all students. Students who participate in SLN range in age from 16 to $70+$. They are both traditional students as well as returning adults. Most students have not taken an on-line course before and report that they have average or high computer skills. Completion rates vary by course and faculty member, just as they do in classroom-based courses.

The majority of the faculty developing and teaching courses through SLN are the regular full-time SUNY faculty. The choice of faculty, including adjunct faculty, is purely a campus-based decision. Early in the development of the SLN program, faculty were provided incentives to participate. For the past year and in the future, this will be the exception. Many faculty were using some technology in their classrooms but many had never used technology at all.

The support that faculty receive comes from full-time professional staff at SLN. Some campuses are now starting to provide this directly to their own faculty. This support includes instructional design assistance, technical support, training, collaborative experiences, and printed and Web-based faculty materials. All of this is part of a structured, well-organized, four-stage faculty development process. This process will be outlined in greater detail in the next section.

The enrollments in the SLN continue to grow dramatically. In 1995-96 SLN had 119 enrollments. This grew to over 6,000 enrollments in 1998-99. We anticipate doubling every year for the next three years.

\section{METHOD}

The technical infrastructure for SLN has evolved over the past five years. When SLN started, there were no coursemanagement systems - so we developed our own, utilizing the industry standard for collaborative computing, Lotus Notes. Since then we have enjoyed the advances of Lotus Domino and the ability to operate on multiple Intel based Windows NT servers at the same time - a tremendous advantage over other commercial packages. When a server goes down, all of the courses are on all of the other servers so students and faculty can continue in this teaching and learning experience. This infrastructure was developed, implemented, and operated by SLN for the first four years. During the past year another system-wide support center has begun to provide server management support while SLN maintains application and program management. SLN has built common applications and processes so that there is consistency for students from the different campuses. For example, students can use a single user name and password to gain access to all of the courses they are taking.

The delivery of SLN courses is through a Web browser so students enjoy text, graphics, and other media. SLN has tried to keep in mind the balance required by slower Internet access capabilities that our students might have. It is also important to note that our on-line courses do not require that every learning activity be Web-based. Faculty may utilize other software applications, simulations, videotapes, other non-computer-based media, and other nontechnology-based activities. An example of such off-line activities might be a student observing a local kindergarten classroom for a Child Psychology and Development course.

Students participate as a cohort and start and end the course according to the calendar of the campus offering the course. Participation is asynchronous throughout the course but it is not self-paced. Most courses have very strong discussion components and faculty have placed a great deal of value in this area. Faculty have been very creative in developing and adjusting their approaches to student assessment. Many instructors have implemented on-line tests and quizzes but often this has been used for student self-assessment. There have not been any mandatory synchronous requirements in the courses. A few faculty have had optional real-time activities and certainly an oncampus student that wants to visit a professor during office hours would not be turned away.

In SLN, the faculty member is ultimately responsible for course development. Our initial experiences have led us to believe that the person teaching the course should also develop the course, so that they have a complete understanding of the course and how it functions. SLN, and now a few campuses, provide instructional design support for faculty. This assistance is part of a well-organized and structured faculty development process. There are 
face-to-face, hands-on training workshops, remote support, and technical support seven days a week through the SLN Help Desk, as well as print and Web-based resources.

Initially the program allocated some compensation from our Sloan grant to the campuses to provide to the faculty in addition to a laptop computer. This is the exception for some selected sponsored-degree programs and the majority of individual courses are handled by the local campus. Some campuses have instituted local approaches to faculty compensation that varies.

We have understood that there are two aspects to faculty persistence with ALN. We have many faculty who develop and teach courses and then go on in subsequent semesters to develop and teach other courses. We also have faculty who have developed and taught one or two courses who then continue to teach those one or two courses. Both aspects are important to the programs and both typically see continuous revisions and enhancements to the courses each semester. More detailed information on faculty persistence will be presented in the Results section.

\section{LESSONS FROM FACULTY DEVELOPMENT "...97.1\% of respondents were either satisfied or very satisfied with their on-line teaching experience." Spring 1999 SLN Faculty Satisfaction \\ Survey}

\section{INTRODUCTION}

This section discusses the evolution of the SLN faculty development and course design methodology as well as the technology used and processes developed for these purposes. It will outline and demonstrate the sequential steps in the process developed by the SLN that have been used to support faculty to develop and deliver more than 400 unique, completely Internet-based courses from 42 different colleges in the SUNY system. We believe that this systematic approach is a significant factor in the high levels of on-line teaching satisfaction that we have achieved in our program.

\section{BACKGROUND}

Beginning in 1994, traditional faculty were hired to create on-line courses for asynchronous delivery into the home via computer. Each faculty member worked with an instructional design partner to implement the course. From fall 1995 through spring 1997, 40 courses were developed and delivered, and the instructional designers conducted interviews, made observations, and collected empirical data. Our objectives during this period were to identify best practices, synthesize scaleable and replicable processes, develop tools and resources, and implement production.

\section{RATIONALE}

With the intention of supporting faculty and course development on a large scale with relatively limited resources, a scaleable and replicable faculty development process was synthesized based on the research conducted by instructional designers. The results are a four-stage faculty development process and a seven-step course design process. Developed and piloted in February 1996, SLN faculty development and course design has been an iterative process. Though the original models remain essentially unchanged, each semester, working with an increasing number of "real" faculty and "real" students, our processes, resources, and support continue to evolve and improve. The SLN faculty development and course design processes are implemented through the SLN Instructional Design Team. The mission of the SLN Instructional Design Team is to help SUNY faculty create technically and instructionally robust learning environments in which to teach and learn.

This comprehensive approach now includes 
- An on-line faculty resource and information gateway

- An asynchronous conference for all developers

- An asynchronous faculty orientation

- A series of workshops for new faculty

- Instructional design sessions for returning faculty

- A comprehensive step-by step course developer's handbook

- A course template

- A faculty help desk

- On-line mechanisms for faculty evaluation of SLN services

- An assigned instructional design partner to support faculty development and course design

A critical factor in our successes has been our ability to evaluate needs, conceptualize solutions, to implement these with active faculty and students, assess our success or failure, and to apply what we have learned as we begin this process again. For example, initially, wanting to model asynchronous instruction, we developed an on-line course to teach faculty how to develop an on-line course. This course was originally designed as a scaffolding mechanism for faculty through the course design phase between face-to-face trainings. Used for three semesters between 1995 and 1996, this course was evaluated by faculty and, based on their feedback, was divided into several of its component parts. It now consists of a printed how-to manual that follows our seven-step course design process, an on-line asynchronous conference for new and returning faculty that is moderated by an experienced faculty person, a on-line faculty orientation moderated by our Help Desk, and the SLN Faculty Center of on-line resources.

\section{Structure of the Faculty Development and Course Design Program}

The on-line faculty conference mirrors our four-stage faculty development process and consists of facilitated asynchronous discussion on issues of asynchronous teaching and learning. This forum provides opportunities for networking between faculty and disciplines. Within the on-line conference faculty can access links that take them to "live" SLN courses for observation (used with permission) that act as models. We recently implemented a separate, on-line asynchronous faculty orientation using the same template. This orientation is moderated by the Help Desk and is designed to introduce faculty to the on-line course environment and specifics of how students interact with the course materials.

Our development cycles are offered in a cohort model. Faculty developing courses for the fall term begin in March and for the spring term, in September. We now also have summer and winter terms, but allow only experienced instructors with repeat courses and provide limited support. 


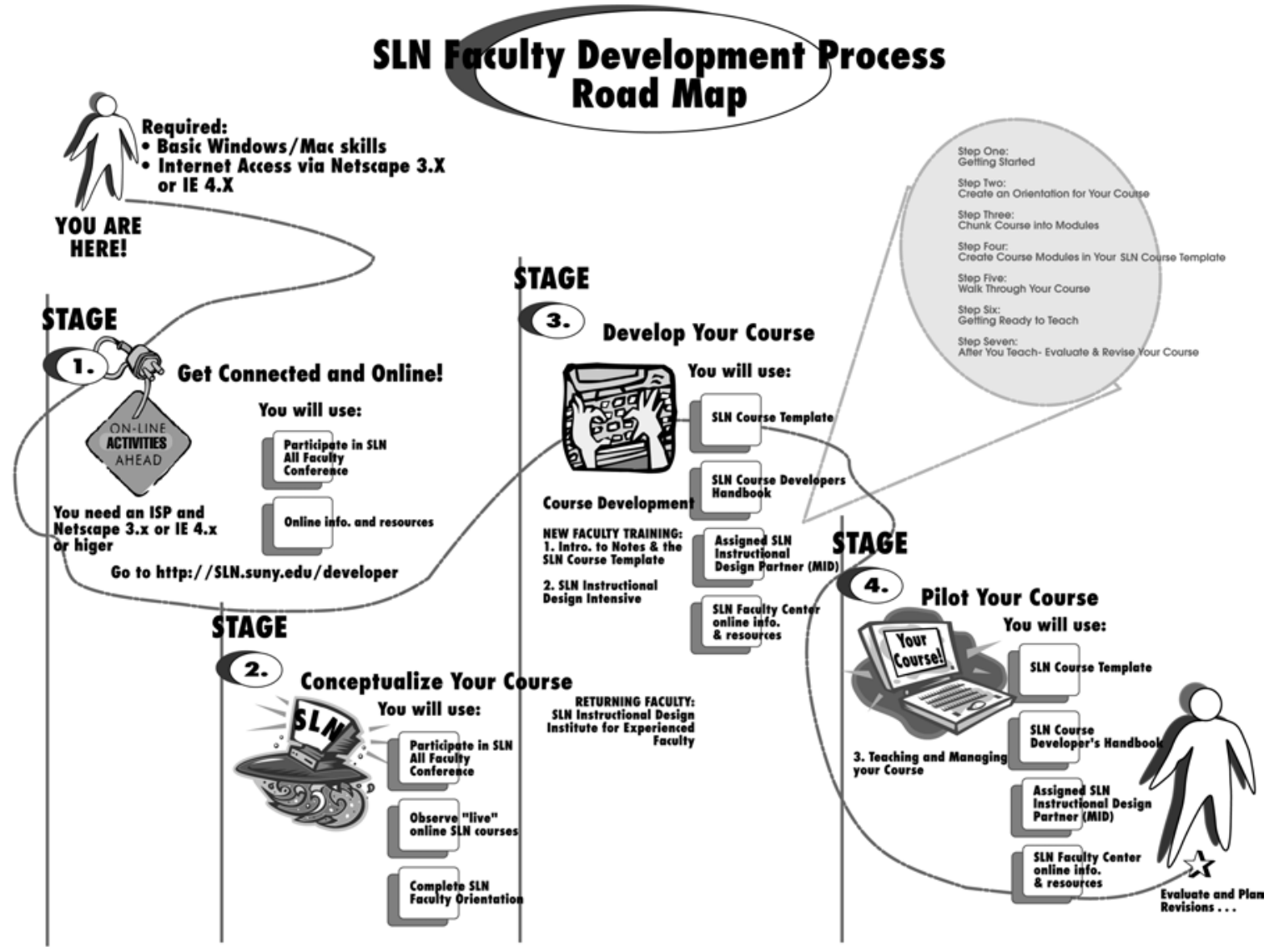

Figure 1: Faculty Development and Course Design Process

\section{METHOD}

SLN program uses a GroupWare application call Lotus Notes in conjunction with a Domino server. A course template was designed and developed specifically for SLN using Lotus Notes and the Domino server technology. There were a number of significant factors that went into the decision in 1994 to choose this product. The nature of GroupWare in facilitating a collaborative working environment for network and remote users and the absence on the market of any other similar product was key. At the time, Lotus Notes was the only integrated product that offered remote use via replication. It also offered a WYSIWYG document creation and sharing. Ultimately, because Lotus Notes allowed relatively easy development and customization of applications and because it was a robust product supported by a reliable company we decided to adopt it as a platform for our template. We chose to develop the SLN course template because, at the time, there were no course-management products on the market such as LearningSpace or WebCT. Later, as we moved to the Domino server for the delivery of courses over the Web, the fact that faculty did not have to learn, understand or use HTML or other Web-page creation technologies, made the Domino technology ideal. We began with the premise that faculty should be able to focus primarily on teaching and students on learning; the technology must, therefore, be as transparent as possible. The relative simplicity of the SLN template for course development and a Web-browser interface for course delivery allowed faculty and students to focus on teaching and learning, not technology.

In addition, we have developed a number of custom database applications to support our administrative, faculty, and student services including

- A student gateway to prepare students for asynchronous on-line learning

- A Student Commons for accessing courses 
- On-line (and printed) course catalogues

- An on-line faculty center

- An on-line faculty development conference

- Moderated faculty and student orientations

- Student and faculty help desk report tracking

- Student and faculty survey data collection

Students access and participate in SLN courses on the World Wide Web using a Web browser. Faculty work in two environments in our program:

- They develop and teach their courses using the SLN course template, a custom Lotus Notes application created by SLN for this purpose. The Lotus Notes/Domino server automatically translates the SLN course template documents into HTML code. Our internal E-mail system is also an important part of the way we communicate and work with faculty. Faculty work with local replicas of the server databases. The ability to work off-line is often cited by faculty as an advantage to our system.

- Faculty also use the Web to preview their course from the students' perspective as they develop their materials. Access to the Web is also necessary to access our many on-line resources.

\section{A. The SLN Course Template}

The SLN course template is designed to allow faculty to quickly and easily create and manage their courses. The template contains a number of documents, forms, and views to create courses. The template allows faculty to easily accomplish the following:

- Create an orientation and syllabus for their course.

- Manage on-line discussions, including private, small group discussions.

- Exchange private documents with students, e.g., a written assignment, essay, or test.

- Create multiple-choice and short-answer quizzes and tests with automatic grading.

- Create and organize their lecture notes and other course materials.

- Create a bibliography of resources, including hot-links to Web sites.

- Create hypertext linking to materials within their site, as well as to other Internet sites.

- Evaluate, track, and grade students' work.

- Make announcements.

- Create a course area where the instructor and students can get to know each other and chat about both course-related and non-course related topics.

The SLN course template is accessible to faculty on the Web during their course design process so that they can see how the course looks and functions from the Web. It comes with pre-designed Web navigation bars to help students navigate their course with ease. It also contains buttons so that students can ask questions and request technical help from any page in their course. Faculty are asked to complete a faculty orientation, which is an on-line course moderated by the SLN Help Desk. This course uses the SLN template and orients faculty to how their course will function from the students' perspective.

\section{B. The Faculty Development Process}

The SLN faculty development process is delivered to a cohort of faculty that has prescribed start and end dates that directly precede the term targeted for delivery of the course. A full cycle for a new faculty person consists of a 


\section{AND LEARNING}

development and delivery cycle. All faculty must go through the faculty development process to participate in the program.

To participate in the program, the instructor's campus must be a participating institution in the SLN program, and have officially proposed the course for development for a specific term. We also suggest that faculty meet the following guidelines.

New faculty should have the following attributes:

- At least basic computer skills

- A willingness to adapt their teaching style to the networked/asynchronous environment

- Availability to participate in the SLN faculty development and course design program that includes: participation in an on-line conference, observation of live on-line courses, attending three, day-long training sessions scheduled throughout the development cycle at various locations around the state, and working closely with an instructional design partner

- Time to fully develop and create their entire on-line course prior to the first day of class

As course development can be time-consuming, we recommend that faculty select a course that they have previously taught rather than develop a new one. It is SLN policy that faculty new to the SLN program develop a single course their first time through the SLN faculty development and course design process.

In our experiences, faculty who have been most successful are those who have a passion for teaching, are willing to rethink how they teach and assess learning, are committed and have the time to develop the course completely prior to the first day of the term, and have institutional support for their on-line teaching endeavors. It is important to note that our program targets participation of mainstream faculty, not the technology-early adopter. It is the comprehensiveness of our support and the robustness of our technology that enable us to have our high levels of success with mainstream faculty and that contribute to the richness of our growing community of on-line instructors and course offerings. Some of our finest instructors would never have made the cut had there been technology proficiency requirements for participation in the program. We have been successful in making the technology as transparent as possible so much so that faculty (and students) do not need to know how it works.

\section{Stage One: Get Connected and On-line}

All new faculty begin together by reviewing our on-line course-developers gateway and resources including

- Links to journal articles and papers regarding on-line teaching and learning

- Recommended guidelines for course development for planning purposes

- Information about the resources, support and services offered to new faculty

- Access to the All Faculty Conference

The purposes of stage one are to get the faculty on-line as soon as possible, so that technology and access issues are addressed right away. It also serves to familiarize the faculty with the program, the components of the faculty development process, and with our Web resources for new faculty. Stage one also begins the reflection period for faculty where they can begin to think about teaching and learning on-line in general and about things specific to their discipline and course. From the Developer Gateway, they are instructed to participate in the on-line All Faculty Conference. This is a facilitated asynchronous resource for all SLN faculty in which they can meet colleagues who are currently developing or preparing to re-teach. An SLN veteran course developer facilitates the conference that includes a faculty lounge/bulletin board area where faculty can chat asynchronously with other faculty. Other highlights of the conference include private small group areas that can be used by the instructional designers with the assigned group of faculty they support, Web links to a variety of Internet resources relevant to teaching and learning on-line, and live, model SLN courses for observation. 
The conference has a variety of objectives:

- Provides opportunity to network with new and experienced faculty.

- Introduces new developers to the SLN Web-course interface.

- Models the role of "student."

- Models effective instructional/course design and moderation of asynchronous discussion.

- Provides an opportunity to participate in asynchronous discussion as students do.

\section{Stage Two: Conceptualize the Course}

Stage two is the conceptualization stage in the faculty development process. Faculty continue to participate in the All Faculty Conference and the emphasis is on course design issues. Faculty focus on student expectations, how students will interact and navigate the course materials, the need for consistency, redundancy, explicitness in design and instructions, designing learning activities, and completing the structure of the course prior to teaching it.

The most important component is the observation of live on-line courses. Course observation is essential for new faculty for a variety of reasons. It allows new faculty to see what a complete course looks like. Through observation, new faculty see how a variety of courses are structured and how each course is unique and defined by the content area and instructor in spite of the use of a template. They also learn about the wide variety of on-line and off-line learning activities that make up a wide range of courses and how courses are organized into modules. Finally they are introduced to different methods of evaluation as different instructors carry them out and witness how a course grows and unfolds with the participation of active students.

Courses for observation are selected as model courses. For the fall 1999 cycle, 18 courses were selected to show a variety of disciplines and approaches to course design. Undergraduate and graduate courses from a mix of SUNY institutions were represented. Among the criteria for selection were

- Effective Instructional Design: Complete and explicit orientation and syllabus area; consistent module structure; explicit, consistent, and redundant instructional cues for students; well-named modules, sections, and documents in the course that convey content or instructional information to the student; clear overviews and expectations for every learning activity; completeness of course

- Effective Teaching Strategies: Timely responses from the instructor; built-in opportunities for interaction with the instructor and other students

- Effective use of technology or the Internet

- Effective collaborative learning activities: discussion; small group activities

- Effective off-line activities

- Innovative "work-arounds" for common problems, ex. science labs or testing

- Model use of any of the features of the course template

- Various and effective approaches to the structure of the learning materials and activities: by topic, by chapter, by steps in a process, by metaphor

- Personality of the instructor

\section{Stage Three: Develop the Course}

Stage three marks the beginning of the seven-step course design process and begins with the first of three, face-toface trainings for new faculty. At the first workshop, faculty are given user names and passwords to our system, and introduced to the course development GroupWare application used by the program including our course template and our E-mail system. In addition, they are given an individualized course template, our course developer 


\section{AND LEARNING}

handbook, and assigned an instructional-design partner. Faculty are asked to bring their syllabi to the training. The first and third trainings are scripted and led by a veteran course developer. We have found that new faculty respond very well to these workshops led by experienced peers. We suspect that a peer instructor who can speak from experience adds elements of trust and the voice of first hand knowledge to the experience.

The objective of the first training is for each new developer to create the main modular structure of his/her course in an individual template to take with them when they leave. We call it chunking their course. Specifics about the program support and services are reviewed and their next steps are outlined. Though benchmarked by the series of three face-to-face trainings with faculty (each now conducted in five locations regionally to accommodate the numbers of faculty being trained), the course-design process is proactively facilitated by the instructional designer according to specific program guidelines and milestones.

During stage three, faculty continue to have access to the All Faculty Conference and the courses for observation. In addition, they are given access to the SLN Faculty Center, a password-protected Website that builds a personalized Web homepage for each faculty person including links to

- Send and receive personal SLN and Internet E-mail

- The SLN Faculty Help Desk

- Get and submit information such as submitting course descriptions and materials order information.

- Download the SLN course template database

- Check SLN program announcements.

- The All Faculty Conference, including live courses for observation, a sample course, and a best practices examples area

- Access link to the individual's course on the Web

The second face-to-face training generally takes place about a month after the first training. This provides time for the faculty to begin working in their template. The Instructional Design Intensive brings the faculty back together to discuss issues in the development of on-line courses and is devised to address the instructor's specific questions related to the creation of learning activities. There is a roundtable component of the workshop to identify and brainstorm issues and solutions and a hands-on portion to demonstrate or implement solutions that emerge from the discussion. Tips, recommendation, guidelines, suggestions, and checklists are collected from the participants and existing information is disseminated. Milestones and next steps are outlined as well as programmatic issues so that faculty continues to understand and feel part of the program.

The remainder of stage three involves the faculty working on the design and development of their course. The role of the Multimedia Instructional Designer (MID) in this stage is to help the faculty develop technically and instructionally robust teaching and learning environments that are appropriate to the instructor's style of instruction, content area, level of the students, and technology being used. Faculty work closely with the MID and endeavor to complete the development of the course prior to the final face-to-face training. Using a series of checklists, the MID conducts an instructional design and technical review of the course to insure its readiness for delivery. The objective of stage three is to complete the course development steps so that during the delivery phase faculty can concentrate on students and teaching the course and not on developing components of the course or dealing with issues of design and technology.

\section{a. The Seven-Step Course Design Process}

Faculty use these steps to guide their course development beginning in stage three of the faculty development process. These steps are followed and supported by all our resources and services including the course developer handbook, the trainings, MID procedures and guidelines, and throughout the SLN Faculty Center of on-line 
resources. We believe that our ability to achieve consistent, successful results with faculty is due to the comprehensive structure and integrated nature of our process, resources, support and services for faculty.

\begin{tabular}{|l|l|}
\hline \multicolumn{1}{|c|}{ STEPS } & \multicolumn{1}{c|}{ ACTIVITIES } \\
\hline $\begin{array}{l}\text { Step One: } \\
\text { Getting Started }\end{array}$ & $\begin{array}{l}\text { Create course proposal } \\
\text { Fill out course profile }\end{array}$ \\
\hline $\begin{array}{l}\text { Step Two: } \\
\text { Create an Orientation for your Course }\end{array}$ & $\begin{array}{l}\text { Edit/Create orientation and syllabus documents } \\
\text { in your SLN course template }\end{array}$ \\
\hline $\begin{array}{l}\text { Step Three: } \\
\text { Chunk your Course into Modules }\end{array}$ & Set up Modules in your SLN course template \\
\hline $\begin{array}{l}\text { Step Four: } \\
\text { Create Learning Activities in your Course Modules }\end{array}$ & $\begin{array}{l}\text { Add learning activities to modules in your SLN } \\
\text { course template }\end{array}$ \\
\hline $\begin{array}{l}\text { Step Five: } \\
\text { Walk Through Your Course }\end{array}$ & $\begin{array}{l}\text { Review and walk through your course } \\
\text { Make revisions }\end{array}$ \\
\hline $\begin{array}{l}\text { Step Six: } \\
\text { Getting Ready to Teach }\end{array}$ & Learn and practice course management skills \\
\hline $\begin{array}{l}\text { Step Seven: } \\
\text { After You Teach—Evaluate and Revise your Course }\end{array}$ & Evaluate and revise your course \\
\hline
\end{tabular}

\section{b. The Multimedia Instructional Design Partner (MID)}

The MID is the fulcrum of the SLN course design process, acting not as a collaborator in the design of the course nor in a clerical support capacity, but as a guide to the faculty. The MID's role, though part editor, part technical support, is primarily as an expert in instructional design and on-line teaching and learning. They are also experts on templates and technology and can guide the faculty to the most effective and efficient ways to achieve their instructional objectives. All MIDs are given an orientation to the program and trained in our technology and the SLN faculty development and course-design process. They observe courses, complete an on-line orientation, participate in course-design reviews, review and familiarize themselves with our guidelines, tips, recommendations, and our course developer handbook. They are also encouraged to take an on-line course, given a practice template and encouraged to develop an SLN course. They become members of the program's instructional design team and participate actively in bi-weekly meetings. As part of the training, new MIDs carry a reduced load of faculty, partner with the lead instructional designer for support, and assume progressively responsible roles at the faculty trainings.

The relationship with faculty is a delicate and negotiated role that, in addition to technical and instructional design expertise, requires diplomacy and high-level interpersonal skills. We have learned that graduate assistants, experienced faculty, and staff may have pre-existing relationships and roles on campus that can inhibit carrying out the role of the MID successfully.

Currently, the SLN instructional design team consists of four full-time MIDs and six campus-based MIDs. The development of the campus-based MID model grew out of a combination of reasons that included, limited program resources to add staff and growing numbers of faculty on individual campuses. The programmatic shift from scaling the project to institutionalizing and sustaining the program added logical rationale to a move in this direction. Building a locally available campus resource facilitates campus ownership and investment in the end makes access for faculty convenient. Campus-based MIDs are trained by the SLN program and function as members of the SLN instructional design team.

The MID functions as a single point of contact between the instructor and the program. The MID team is kept up to date on the latest programmatic information, procedural changes, technology or instructional design issues, and provides a forum for designers to share information and tips, and the opportunity to brainstorm and problem-solve solutions to design and technology issues with each other. Working closely with the faculty and having the SLN instructional design team to rely on puts the MIDs in an advantageous position to share information, strategies, and solutions with their cohort of assigned faculty and with each other. The instructional design (ID) team uses a 
common GroupWare database to post questions, document common issues and solutions, disseminate documentation and share information between meetings. The ID team is geographically dispersed across the state and communicates and shares information asynchronously. Each MID is assigned a maximum of 30 to 40 new faculty to support per term and is responsible for follow-through on the development of their assigned faculty as online instructors and the course design process according to programmatic guidelines and schedules. The MIDs participate in the training sessions for their regional locations.

The comprehensiveness of our processes, resources, support, and services facilitates the MIDs in their pivotal role and allows them to do their jobs in a well-documented, organized manner. The unique role of the MID in the SLN program is a distinguishing factor in our faculty development and course design processes and we believe, based on our high degrees of satisfaction with both faculty and students, critical to our successes in both faculty development and course design.

\section{Stage Four: Pilot the Course}

Stage four of the SLN Faculty Development Process begins with the third face-to-face training. The Teaching and Managing Your Course workshop marks the transition for faculty from the course development to the delivery. This training prepares them for students entering their course. Program staff explain to faculty how students access the system and access their course and discuss any questions faculty may have. A roundtable discussion with veteran faculty caps the development cycle at this training. This roundtable provides an opportunity for new faculty to meet and talk with experienced faculty, to ask questions, and for our experienced faculty to share what they know and what to expect with new faculty.

Stage four is the pilot-your-course stage. The MID closely monitors new faculty and their new courses during the first three to four weeks of the semester. Weekly check-ins, telephone, and E-mail communications and intervention, when necessary, take place behind the scenes. Faculty are asked to take notes on what is working and what needs improvement as they teach the course to make evaluations and revisions easier the next time they teach the course.

Stage four ends with an on-line survey to assess faculty satisfaction and to help us learn more about teaching and learning on-line and to help us improve our services, support, and resources for faculty.

\section{CONCLUSION}

Faculty performance is not assessed at the SLN program level. SLN does not have academic oversight over courses nor is it in a position to evaluate the instructors or their courses. Campuses deal with these issues on an individual basis, most often in the ways traditional courses and faculty are evaluated. The program does, however, have a formal instructional design review process conducted at the end of the course design process and conducted by the assigned instructional design partners. With a series of checklists available both to the instructors and the MIDs, the MIDs conduct the ID review to "pre-flight" the course in anticipation of the first day of class. A formal review report is written and given to the instructor and any recommended revisions are discussed with the instructor and implemented. The ID team marks success by faculty who want to teach again and do, by those that continue to develop new courses, and by those that recommend teaching in the program and by this method to colleagues.

\section{A. SLN Best Practices}

- Good on-line instructional practices are independent of software.

- Just because you can does not mean you should.

- A well-designed course creatively leverages the options and recognizes the limitations of the on-line learning environment.

- Assume nothing.

- If you do something and it does not work (or it breaks something), do not do it again. 
- Just because a course is on-line does not mean it all has to be on-line.

- Asynchronous distance learning does not mean self-paced.

- First make it work and then make it pretty.

\section{B. Specific SLN Best Practices}

- Create opportunities for interaction with students and between students.

- Create/use activities that build a sense of class community.

- Think literal.

- Talk; do not write.

- Use the structure of the course to convey information about the course, content, task.

- Provide explicit instructions cues and signposts for students.

- Be flexibly firm.

- Be consistent, redundant, and complete in the structure and creation of your course.

\section{Comprehensive Support to Develop Effective On-line Faculty}

- Faculty-driven course design or pedagogy must not be imposed by the course management application or the instructional designer.

- Faculty must develop the course themselves.

- Opportunities for reflection, evaluation, and revision.

- Opportunities for participation in on-line courses or discussion.

- Observation of live on-line courses.

- Access to experienced faculty, opportunities for interdisciplinary networking, peer Support/training.

- Individual instructional design support and technical support.

- Reliable stable network and technology.

- Template that makes technology transparent.

- Collecting and sharing best practices.

- Resources and support in a variety of media.

\section{Some of Our Current Challenges}

- Enhancing support and services for our returning faculty, now the majority. Providing the next level instructional design support, evaluation and revision, and providing opportunities for discipline-specific networking and best practices.

- Training faculty at a distance.

- Out-of-term development.

- Training faculty to deliver courses that they did not develop.

- Campus-based MIDs: Transferring our models and processes to the campus. Loosing control of the faculty development process and influence on course design. 


\section{AND LEARNING}

We have now gone beyond our initial questions of what works. Will it scale? And how do we institutionalize and sustain this program? Our questions now include what specific elements of instructional or course design are most effective? What specific on-line teaching strategies are most effective? Does teaching on-line affect/change/improve how you teach in the classroom? Can our processes, models, and generic resources be successfully implemented by individual faculty, departments, or campuses outside the context of the SLN program? As we continue to grow and evolve we will continue to learn from our faculty and share with them what we learn.

Successful, satisfied on-line instructors have effective course designs and effective teaching practices. SLN has been able to achieve high levels of faculty satisfaction efficiently and consistently on a large scale with a comprehensive approach to the support of SUNY faculty, their development as on-line instructors, and effective support and attention to the instructional design of their on-line courses. Specific data is presented in the next section.

\section{THE SPRING 1999 SLN FACULTY SATISFACTION SURVEY}

\section{RESULTS}

In spring 1999, faculty teaching courses in the SLN completed a survey that may be useful in understanding questions related to faculty satisfaction in asynchronous on-line instruction. So far, 105 instructors have completed the survey, approximately $40 \%$ of faculty for the spring 1999 semester. The factors that significantly contribute to faculty satisfaction in the teaching of their courses are student performance, level of student interaction in the course, reason for choosing to teach on-line, satisfaction with the SLN, a positive perception of the effects of the technology, low levels of technical difficulties, and how well the faculty got to know their students.

\section{A. Student Performance}

When asked to rate their students' performance in the on-line classroom relative to the traditional classroom, approximately $45 \%$ of the respondents felt that their on-line students performed better than their classroom students did. About $44 \%$ felt there was no difference in the performance and only $8.6 \%$ felt that their classroom students performed better.

Note: Ratings are based on a Likert scale of I-4. I= a very high level of satisfaction, 4 = a very low level of satisfaction.

Student Performance

\begin{tabular}{|l|l|l|l|l|}
\hline & Frequency & Percent & $\begin{array}{c}\text { Valid } \\
\text { Percent }\end{array}$ & $\begin{array}{c}\text { Cumulative } \\
\text { Percent }\end{array}$ \\
\hline On-line performed better & 47 & 44.8 & 44.8 & 44.8 \\
No difference & 46 & 43.8 & 43.8 & 88.6 \\
Classroom performed better & 9 & 8.6 & 8.6 & 97.1 \\
I did not teach in class & 3 & 2.9 & 2.9 & 100.0 \\
\hline Total & 105 & 100.0 & 100.0 & \\
\hline
\end{tabular}

When the faculty's assessments of their students' performance are compared to their level of satisfaction with their on-line teaching experience, perhaps not surprisingly, those who felt that their on-line students did better also felt significantly more satisfied with on-line teaching. 
Satisfaction with Teaching X Student Performance

Satisfaction with Teaching

\begin{tabular}{|l|l|l|l|}
\hline \multicolumn{1}{|c|}{ Student Performance } & Mean & \multicolumn{1}{|c|}{$\mathbf{N}$} & $\begin{array}{c}\text { Std. } \\
\text { Deviation }\end{array}$ \\
\hline On-line performed better & 1.3191 & 47 & .4712 \\
\hline No difference & 1.6522 & 46 & .5257 \\
\hline Classroom performed better & 1.8889 & 9 & .6009 \\
\hline I did not teach in class & 1.6667 & 3 & .5774 \\
\hline Total & 1.5238 & 105 & .5388 \\
\hline
\end{tabular}

\section{ANOVA Table}

Satisfaction with Teaching

\begin{tabular}{|l|l|l|l|l|l|}
\hline Student Performance & $\begin{array}{l}\text { Sum of } \\
\text { Square }\end{array}$ & df & $\begin{array}{c}\text { Mean } \\
\text { Square }\end{array}$ & F & Sig. \\
\hline Between groups & 3.987 & 3 & 1.329 & 5.123 & .002 \\
Within groups & 26.203 & 101 & .259 & & \\
\hline Total & 30.190 & 104 & & \\
\hline
\end{tabular}

\section{B. Interaction with Students}

The survey also asked the faculty to rate the level of interaction between students in their on-line classes relative to students in the traditional classroom. Approximately $48 \%$ felt that the level of interaction between their on-line students was Higher or Much Higher than that of their classroom students. Two-thirds of the respondents felt that there was at least no difference. Approximately one-third felt that the level of interaction was lower for their on-line student that for classroom students.

\section{Student Interaction}

\begin{tabular}{|l|l|l|l|l|}
\hline & Frequency & Percent & $\begin{array}{c}\text { Valid } \\
\text { Percent }\end{array}$ & $\begin{array}{c}\text { Cumulative } \\
\text { Percent }\end{array}$ \\
\hline Much higher & 14 & 13.3 & 13.3 & 13.3 \\
Higher & 36 & 34.3 & 34.3 & 47.6 \\
The same & 20 & 19.0 & 19.0 & 66.7 \\
Lower & 24 & 22.9 & 22.9 & 89.5 \\
Much lower & 11 & 10.5 & 10.5 & 100.0 \\
\hline Total & 105 & 100.0 & 100.0 & \\
\hline
\end{tabular}

When faculty ratings for student interaction are compared to their level of satisfaction with their on-line teaching experience, those who rated their students level of interaction as higher or much higher were significantly more satisfied with the experience than those who felt it was much lower.

Satisfaction with Teaching $X$ Student Interaction Satisfaction with Teaching

\begin{tabular}{|l|l|l|l|}
\hline Student Interaction & Mean & N & $\begin{array}{c}\text { Std. } \\
\text { Deviation }\end{array}$ \\
\hline Much higher & 1.2143 & 14 & .4258 \\
\hline Higher & 1.4167 & 36 & .5542 \\
\hline The same & 1.4500 & 20 & .5104 \\
\hline Lower & 1.7083 & 24 & .4643 \\
\hline Much lower & 2.0000 & 11 & .4472 \\
\hline Total & 1.5238 & 105 & .5388 \\
\hline
\end{tabular}




\section{AND LEARNING}

ANOVA Table

Satisfaction with Teaching

\begin{tabular}{|l|l|l|l|l|l|}
\hline Student Interaction & $\begin{array}{l}\text { Sum of } \\
\text { Square }\end{array}$ & df & $\begin{array}{c}\text { Mean } \\
\text { Square }\end{array}$ & F & Sig. \\
\hline Between groups & 5.175 & 4 & 1.294 & 5.172 & .001 \\
Within groups & 25.015 & 100 & .250 & & \\
\hline Total & 30.190 & 104 & & \\
\hline
\end{tabular}

\section{Reasons for Teaching an On-line Course}

Faculty were also asked why they chose to teach an on-line course. The most common responses were "an interest in on-line teaching and learning" and an "interest in technology and the internet" which accounted for nearly $70 \%$ of responses. Less than $2 \%$ of respondents felt that they wanted to or needed to telecommute and less than $3 \%$ chose to teach due to fear of being left behind.

Why On-line?

\begin{tabular}{|l|l|l|l|l|}
\hline & Frequency & Percent & $\begin{array}{c}\text { Valid } \\
\text { Percent }\end{array}$ & $\begin{array}{c}\text { Cumulative } \\
\text { Percent }\end{array}$ \\
\hline Curiosity & 8 & 7.6 & 7.6 & 7.6 \\
Marketability of skills & 9 & 8.6 & 8.6 & 16.2 \\
Want/need to telecommute & 2 & 1.9 & 1.9 & 18.1 \\
Course is only offered on-line & 2 & 1.9 & 1.9 & 20.0 \\
Interest in technology/internet & 25 & 23.8 & 23.8 & 43.8 \\
Fear of being left behind & 3 & 2.9 & 2.9 & 46.7 \\
Other & 8 & 7.6 & 7.6 & 54.3 \\
Interest in on-line teaching and learning & 48 & 45.7 & 45.7 & 100.0 \\
\hline Total & 105 & 100.0 & 100.0 & \\
\hline
\end{tabular}

When responses for motivation for on-line teaching are compared to satisfaction with the experience the results indicate that those whose motivation was an interest in the Internet or on-line teaching rated their satisfaction as higher than those whose motivation was that the course was only offered on-line, fear of being left behind, marketability of skills, research, curiosity, or other.

Satisfaction with teaching $X$ Why did you want to teach on-line?

Satisfaction with Teaching

\begin{tabular}{|l|l|l|l|}
\hline \multicolumn{1}{|c|}{ Why On-line? } & Mean & \multicolumn{1}{|c|}{$\mathbf{N}$} & \multicolumn{1}{c|}{$\begin{array}{c}\text { Std. } \\
\text { Deviation }\end{array}$} \\
\hline Curiosity & 1.6250 & 8 & .5175 \\
Marketability of skills & 1.6667 & 9 & .5000 \\
Want/need to telecommute & 1.0000 & 2 & .0000 \\
Course is only offered on-line & 2.5000 & 2 & .7071 \\
Interest in technology/internet & 1.5200 & 25 & .5099 \\
Fear of being left behind & 1.6667 & 3 & .5774 \\
Other & 1.8750 & 8 & .3536 \\
Interest in on-line teaching and learning & 1.3958 & 48 & .5355 \\
\hline Total & 1.5238 & 105 & .5388 \\
\hline
\end{tabular}

\section{ANOVA Table}

Satisfaction with Teaching

\begin{tabular}{|l|l|l|l|l|l|}
\hline Why On-line? & $\begin{array}{l}\text { Sum of } \\
\text { Square }\end{array}$ & df & $\begin{array}{c}\text { Mean } \\
\text { Square }\end{array}$ & F & Sig. \\
\hline Between groups & 4.555 & 7 & .651 & 2.462 & .023 \\
Within groups & 25.636 & 97 & .264 & & \\
\hline Total & 30.190 & 104 & & & \\
\hline
\end{tabular}




\section{Satisfaction with SLN Program}

The faculty were also asked to rate their level of satisfaction with the SLN. Of the 105 respondents, 73 rated their satisfaction level as a great deal. Another 32 said they were satisfied. There were no faculty who responded either not very satisfied or not satisfied at all.

On-line Satisfaction

\begin{tabular}{|l|l|l|l|l|}
\hline & Frequency & Percent & $\begin{array}{c}\text { Valid } \\
\text { Percent }\end{array}$ & $\begin{array}{c}\text { Cumulative } \\
\text { Percent }\end{array}$ \\
\hline A great deal & 73 & 69.5 & 69.5 & 69.5 \\
Somewhat & 32 & 30.5 & 30.5 & 100.0 \\
\hline Total & 105 & 100.0 & 100.0 & \\
\hline
\end{tabular}

When respondents satisfaction level with the SLN program are compared to their satisfaction level for on-line teaching, those who rated their satisfaction level with SLN as a great deal were significantly more satisfied with their teaching experience than those who rated their satisfaction with SLN as merely satisfied.

Satisfaction with Teaching X Satisfaction with SLN

Satisfaction with Teaching

\begin{tabular}{|l|l|l|l|}
\hline SLN Satisfaction & Mean & N & $\begin{array}{c}\text { Std. } \\
\text { Deviation }\end{array}$ \\
\hline A great deal & 1.4225 & 71 & .5254 \\
Somewhat & 1.7353 & 34 & .5110 \\
\hline Total & 1.5238 & 105 & .5388 \\
\hline
\end{tabular}

ANOVA Table

Satisfaction with Teaching

\begin{tabular}{|l|l|l|l|c|c|}
\hline SLN Satisfaction & $\begin{array}{l}\text { Sum of } \\
\text { Square }\end{array}$ & df & $\begin{array}{c}\text { Mean } \\
\text { Square }\end{array}$ & F & Sig. \\
\hline Between groups & 2.249 & 1 & 2.249 & 8.290 & .005 \\
Within groups & 27.942 & 103 & .271 & & \\
\hline Total & 30.190 & 104 & & & \\
\hline
\end{tabular}

\section{E. Effects of the Technology}

Respondents to the survey were also asked how they felt about the effects of the technology used in teaching an online course. When asked to what extent they agreed with the statement, "Overall, I think the technology had a positive effect on my teaching", approximately $91 \%$ agreed, with approximately $42 \%$ feeling they agreed strongly and another $50 \%$ stating that they agreed.

Effect of the Technology Positive

\begin{tabular}{|l|l|l|l|l|}
\hline & Frequency & Percent & $\begin{array}{c}\text { Valid } \\
\text { Percent }\end{array}$ & $\begin{array}{c}\text { Cumulative } \\
\text { Percent }\end{array}$ \\
\hline Strongly Agree & 44 & 41.9 & 41.9 & 41.9 \\
Agree & 52 & 49.5 & 49.5 & 91.4 \\
Disagree & 9 & 8.6 & 8.6 & 100.0 \\
\hline Total & 105 & 100.0 & 100.0 & \\
\hline
\end{tabular}

When faculty ratings for the effects of the technology are compared to their level of satisfaction with on-line teaching, those who felt that they agreed strongly were significantly more satisfied with teaching than either those who merely agreed or those who disagreed. Also, those who agreed were significantly more satisfied than those who disagreed. 


\section{Satisfaction with On-line Teaching by Effects of the Technology}

Satisfaction with Teaching

\begin{tabular}{|l|l|l|l|}
\hline Effect of the Technology Positive & Mean & N & $\begin{array}{c}\text { Std. } \\
\text { Deviation }\end{array}$ \\
\hline Strongly agree & 1.2727 & 44 & .4505 \\
Agree & 1.6923 & 52 & .6116 \\
Disagree & 2.1111 & 9 & .3333 \\
\hline Total & 1.5524 & 105 & .5880 \\
\hline
\end{tabular}

\section{ANOVA Table}

Satisfaction with Teaching

\begin{tabular}{|l|l|l|l|l|l|}
\hline Effect of the Technology Positive & $\begin{array}{l}\text { Sum of } \\
\text { Square }\end{array}$ & df & $\begin{array}{l}\text { Mean } \\
\text { Square }\end{array}$ & F & Sig. \\
\hline Between groups & 7.269 & 2 & 3.634 & 12.920 & .000 \\
Within groups & 28.693 & 102 & .281 & & \\
\hline Total & 35.962 & 104 & & & \\
\hline
\end{tabular}

\section{F. Technical Difficulties}

Faculty were also asked how technical difficulties affected their teaching. Approximately $51 \%$ felt that technical difficulties did not affect their teaching at all. Among these instructors, 27\% felt that they had had no technical difficulties and another 24\% felt that although they had some technical difficulties, these did not affect their teaching. Another 16\% felt that, although technical difficulties had affected their teaching, these difficulties were no greater than those experienced with classroom teaching. Approximately $31 \%$ felt that technical difficulties made their teaching experience somewhat more difficult and another $2 \%$ felt that such difficulties made their teaching experience much more difficult.

\section{Technical Difficulties}

\begin{tabular}{|l|l|l|l|l|}
\hline & Frequency & Percent & $\begin{array}{c}\text { Valid } \\
\text { Percent }\end{array}$ & $\begin{array}{c}\text { Cumulative } \\
\text { Percent }\end{array}$ \\
\hline Not applicable: no tech. difficulties & 29 & 27.6 & 27.6 & 27.6 \\
Not applicable: tech. difficulties & 25 & 23.8 & 23.8 & 51.4 \\
did not affect my teaching & & & & \\
No difference & 17 & 16.2 & 16.2 & 67.6 \\
Yes: somewhat more difficult & 32 & 30.5 & 30.5 & 98.1 \\
Yes: much more difficult & 2 & 1.9 & 1.9 & 100.0 \\
\hline Total & 105 & 100.0 & 100.0 & \\
\hline
\end{tabular}

When ratings for the effects of technical difficulties are compared to on-line teaching satisfaction, those who felt that technical difficulties had not affected their teaching are compared to those who felt it had, the former are significantly more satisfied than the latter.

\section{Report}

Satisfaction with Teaching

\begin{tabular}{|l|l|l|l|}
\hline Effect of Technical Difficulties & Mean & $\mathbf{N}$ & $\begin{array}{c}\text { Std. } \\
\text { Deviation }\end{array}$ \\
\hline At least no difference & 1.4648 & 71 & .6055 \\
More difficult & 1.7353 & 34 & .5110 \\
\hline Total & 1.5524 & 105 & .5880 \\
\hline
\end{tabular}


ANOVA Table

Satisfaction with Teaching

\begin{tabular}{|l|l|l|l|l|l|}
\hline Effect of Technical Difficulties & $\begin{array}{l}\text { Sum of } \\
\text { Square }\end{array}$ & df & $\begin{array}{l}\text { Mean } \\
\text { Square }\end{array}$ & F & Sig. \\
\hline Between groups & 1.682 & 1 & 1.682 & 5.055 & .027 \\
Within groups & 34.280 & 103 & .333 & & \\
\hline Total & 35.962 & 104 & & \\
\hline
\end{tabular}

\section{G. Knowledge of Students}

Faculty were also asked to rate how well they knew their on-line students relative to their classroom students. Approximately $64 \%$ felt that their was at least no difference with $7 \%$ responding that they knew their on-line students much better another $33 \%$ stating they knew them better and $24 \%$ feeling they knew them the same. Approximately $35 \%$ felt they did not know their on-line students as well and another $1 \%$ felt that they did not know them at all.

Know Students
\begin{tabular}{|l|l|l|l|l|}
\hline & Frequency & Percent & $\begin{array}{c}\text { Valid } \\
\text { Percent }\end{array}$ & $\begin{array}{c}\text { Cumulative } \\
\text { Percent }\end{array}$ \\
\hline Much better & 7 & 6.7 & 6.7 & 6.7 \\
Better & 35 & 33.3 & 33.3 & 40.0 \\
The same & 25 & 23.8 & 23.8 & 63.8 \\
Not as well & 37 & 35.2 & 35.2 & 99.0 \\
Not at all & 1 & 1.0 & 1.0 & 100.0 \\
\hline Total & 105 & 100.0 & 100.0 & \\
\hline
\end{tabular}

When ratings for familiarity with students are compared to on-line teaching satisfaction those who felt they knew their on-line students better than their classroom students were significantly more satisfied than those who felt they did not know them as well.

How well did you know your students?

Satisfaction with Teaching

\begin{tabular}{|l|l|l|l|}
\hline $\begin{array}{c}\text { How well did you get } \\
\text { to know your students? }\end{array}$ & Mean & $\mathbf{N}$ & $\begin{array}{c}\text { Std. } \\
\text { Deviation }\end{array}$ \\
\hline Knew on-line students better & 1.3810 & 42 & .6608 \\
Knew classroom students better & 1.6842 & 38 & .5253 \\
\hline Total & 1.5250 & 80 & .6157 \\
\hline
\end{tabular}

ANOVA Table

Satisfaction with Teaching

\begin{tabular}{|l|l|l|l|l|l|}
\hline $\begin{array}{c}\text { How well did you get } \\
\text { to know your students? }\end{array}$ & $\begin{array}{c}\text { Sum of } \\
\text { Square }\end{array}$ & df & $\begin{array}{c}\text { Mean } \\
\text { Square }\end{array}$ & F & Sig. \\
\hline Between groups & 1.835 & 1 & 1.835 & 5.090 & .027 \\
Within groups & 28.115 & 78 & .360 & & \\
\hline Total & 29.950 & 79 & & & \\
\hline
\end{tabular}

\section{DISCUSSION}

"I can honestly tell you that I would never consider teaching an on-line class without the kind of support you all provided. Thanks to all of you for your hard work." 


\section{AND LEARNING}

It seems that certain factors significantly impact faculty satisfaction with on-line teaching. The factors that appear to contribute to faculty satisfaction in the teaching of their SLN courses are: student performance; level of student interaction in the course; reason for choosing to teach on-line; satisfaction with the SLN; a positive perception of the effects of the technology; low levels of technical difficulties; and how well the faculty got to know their students.

While it is difficult to control student performance completely, it appears that for the most part, the high degree of faculty satisfaction with on-line teaching in SLN can be accounted for by the fact that many faculty felt that students performed better in this environment than in the classroom. From these results it seems that characterizations of the on-line environment as a digital diploma mill are somewhat inaccurate. Results from faculty who have actually taught on-line courses attest to the high quality of work and level of interaction that is achieved in this mode of instruction.

One could easily imagine that some of these factors are the same ones that contribute to satisfaction in the regular classroom. However, a few differences are worth noting. For example, while analysis of student satisfaction with on-line learning reveals that students' biggest concerns are interaction with the teacher the factor that most influenced faculty satisfaction was interaction between students. This may reflect the faculty's more progressive ideas regarding the role of the teacher as facilitator that may not yet coincide with student expectations of the instructor's role. This seems especially likely inasmuch as students in this environment tend to be older and may not have experienced education that tends to be student centered and/or based in collaboration.

There was a very high degree of satisfaction among the faculty responding to this survey. It is, therefore, somewhat difficult to make great distinctions regarding what led to that satisfaction. It appears that having an interest in the Internet, technology, or on-line teaching itself is more closely associated with higher levels of satisfaction than other motivations such as fear or lack of choice. However, even faculty whose motivations were not directly related to technology or on-line teaching were, nonetheless, at least somewhat satisfied with the experience.

For our purpose as an organization, the results showing that faculty who rated their level of satisfaction with SLN as high also rated their satisfaction with on-line teaching as high are perhaps the most important to emerge from this study. A correlation between satisfaction with SLN and the creation and implementation of on-line learning indicates that we are achieving our ultimate goal- to assure that high quality instruction is available to students anytime and anywhere.

\section{FACULTY SATISFACTION WITH THE UNIVERSITY AT ALBANY'S SLN MASTER'S DEGREE PROGRAM IN INSTRUCTIONAL TECHNOLOGY}

\section{INTRODUCTION}

We began working on the on-line version of our master's degree in Instructional Technology in spring 1997. Judy Genshaft, the Vice-President of Academic Affairs at the University at Albany, brought together several members of Professor Swan's department, Educational Theory and Practice (ETAP), and asked if they were interested in developing a program that would offer a masters degree entirely asynchronously. When the ETAP department said yes, Genshaft introduced them to Eric Frederickson at SUNY.

Like most SLN degree programs, UA's was created from an existing face-to-face curriculum - the master's degree in Curriculum Design and Instructional Technology (CDIT). This program was designed both to meet the certification needs of practicing teachers in areas other than those covered by our secondary permanent certification programs, and to offer specialized training and retraining in curriculum, instruction, and the burgeoning field of educational technology. It was this latter discipline on which we choose to focus our attention, in part, from a shared 
belief in design as a particularly important path to understanding. How could we pass up the chance to practice what we preach?

The CDIT degree is a 30-credit, 10-course, master's program, half of which is prescribed, half of which is designed by the student in consultation with an advisor. Proscribed courses include two educational foundations courses- one in human learning and one in social thought, a course in instruction, a course in either technology or curriculum, and a course in educational research. Enrollment in the CDIT program is open to any student with an undergraduate degree whose GPA is 3.0 or better.

We agreed to develop and teach ten Web-based courses that would collectively satisfy the CDIT degree requirement. Our on-line courses, however, are open to all ETAP graduate students. Students may mix and match on-line and face-to-face courses to satisfy the degree requirements.

We offered our first on-line courses in fall 1997. The most technology literate among us were the first to jump at the opportunity. Carla Meskill created an on-line version of her Language, Literacy and Technology class. Joseph Bowman developed an on-line version of his Web-design course, Computing and Education II. Karen Swan put her introductory Computing and Education I course on-line. It has been offered on-line continuously (with graduate assistants handling most of the workload) ever since. In spring 1998, Dr. Meskill and Professor Swan collaborated on the on-line version of Media in Teaching and Learning. In fall 1998, Systematic Design of Instruction (taught by Robert Bangert-Drowns) was added to satisfy the instruction requirement and Teaching in Context (taught by Audrey Champagne) to satisfy the social thought requirement. In spring 1999, Ted Bredderman developed an online version of the required Research Seminar, and Professor Swan recreated her Mass Media and Education course on-line. This coming fall we will add the last two courses necessary to completing the degree. Meskill and Peter Shea are developing the introductory Educational Research course in the SLN format, and Vic Kouba is creating the last required course, Learning in the Academic Disciplines.

The intended audience for our on-line CDIT courses was people interested in instructional technology but separated in space and/or time from our face-to-face classes. Faculty have found, however, that on-line courses are also very attractive to traditional students, practicing teachers who often have responsibilities outside of the regular school day that make face-to-face classes difficult to attend.

\section{RATIONALE}

The primary motivating factors that led to the development of an on-line master's degree program centered on the chance to experiment with the new medium. Many of the faculty specialize, at least in part, in instructional technology. For these faculty, then, course development was a learning as well as a teaching experience. On-line courses also allowed us to offer our students the opportunity to experience advanced educational technologies as they learned about them.

ETAP faculty were given monetary stipends, course reduction, laptops, and a budget of $\$ 1,000$ for additional resources to develop and teach the SLN version of their course at least once. Participation in the program was strictly voluntary. All courses were developed as on-line versions of face-to-face courses by the faculty members normally responsible for them.

\section{BACKGROUND INFORMATION}

There had been no completely asynchronous courses given at UA previously, although some very interesting mixed face-to-face and on-line courses had been created for Project Renaissance, and there had been a variety of experiments with satellite and two-way video-distance learning. In fact, the SLN project was turned down by two other departments before we accepted it. 


\section{AND LEARNING}

There are twelve faculty members in the ETAP department - three full, seven associate, and two assistant professors. Of these, seven faculty created courses for the on-line degree —one full, five associate, and one assistant professor participated in the program. Participating faculty average more than 15 years of teaching experience in higher educational settings, and, of course, all are educational specialists. Three of the faculty members teaching SLN courses had more than ten years experience with the use of information technology, including experience in multimedia design. Three of the faculty members were completely comfortable with it, and used it frequently in their classes. One faculty member was a complete novice. She had a graduate student help her develop and teach the course. All the faculty members had the usual SLN access to MIDs assigned to them, and to the SLN Help Desk staff. No support was provided by the UA.

Enrollments in the on-line courses are higher than they had been in the face-to-face versions of the courses (see Figures 1 and 2), something that had not been anticipated. They would be higher still if a cap were not in place. To cope with high enrollments faculty assign graduate students to teach sections of courses under the supervision of the faculty members who created the courses. Because of the high and continually growing interest in the program, another faculty member in the field is being sought.

Learners in the on-line courses are, if anything, better than traditional on-campus learners. On-line learners include many working professionals from around the state who would not be able to attend on-campus classes but enroll in on-line courses. This professional presence has added tremendously to the quality of the courses.
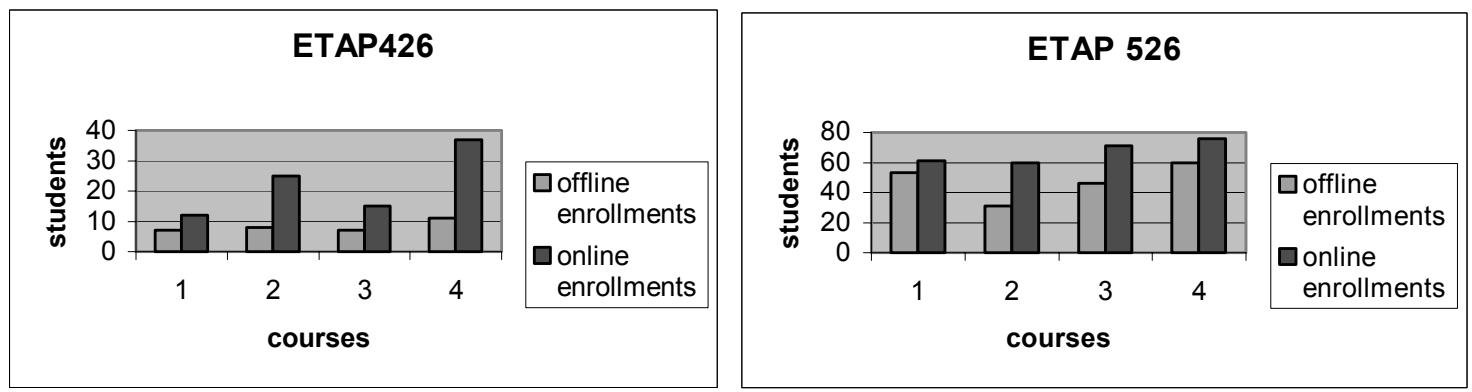

Figure 1

Comparison of Traditional Enrollment in ETAP 426 and 526 with Enrollment in On-line Version

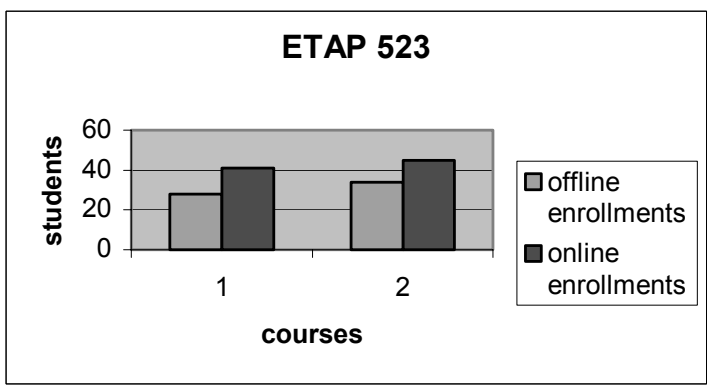

Figure 2

A Comparison of Traditional Enrollment in ETAP 523 with Enrollment in On-line Version

\section{METHOD}

\section{A. Technology and Infrastructure}

CDIT courses were developed in Lotus Notes using custom templates provided by SLN (designed to run on both PC and Macintosh platforms). The courses reside on multiple servers maintained by SLN. A decision was made at SLN 
to keep all courses as simple as possible so that they could be accessed by the greatest number of students. The courses are, therefore, primarily text-based, although many of our courses (especially those concerned with media) do utilize graphic organizers and images.

\section{B. Content Delivery}

In this and the following section, Professor Swan will focus on the courses she teaches-Computing in Education I, Media in Teaching and Learning, and Mass Media and Education. These courses, as are all the courses in the program, are delivered according to a regular 14-week semester schedule. Professor Swan does not insist (through grade reduction or other devices) on specific due dates for work in her classes. However, students are strongly encouraged to keep up with assignments that are given on a weekly basis.

All of Professor Swan's courses are portfolio-based—students are given many small assignments of a variety of types (see below) that are assessed on a pass/fail basis for a set number of points. They just have to do it. Sometimes (rarely), extra points for especially good assignments and/or take off points for extremely poor assignments are applied. Students can redo poor assignments for full credit. Students are primarily assessed on the basis of written assignments, projects, and discussion. As Professor Swan has become more familiar with asynchronous formats, she has come to put more of an emphasis on discussion because she has been very impressed with the quality of on-line discussion. Indeed, she speculates, this is one of the strongest features of asynchronous environments. For similar reasons, she has never used tests or quizzes, as she believes they are weakly implemented asynchronous formats. Figures 5 and 6 show the assessment schemas for two of these courses.

\section{Organization and Evolution}

Faculty members have sole responsibility for implementing their courses on-line, but they are given lots of help (on an as-needed basis) from SLN multimedia instructional designers (for instructional design issues) and Help Desk staff (for technical issues). Because the CDIT degree program is in instructional technology, faculty members need less help than typical, but help was available when needed. Although local support was promised, it has been slow in coming.

ETAP faculty were given monetary stipends, course reduction, laptops, and a budget of $\$ 1,000$ for additional resources to develop and teach the SLN version of their course at least once. Monies came from the Sloan Foundation through SLN. Participation in the program was strictly voluntary. All courses were developed as on-line versions of face-to-face courses by the faculty members normally responsible for them.

The Computing in Education (ETAP 426/526) course has been offered four times. Professor Swan taught the first two semesters. In the last two semesters, enrollments have been so high two sections taught by graduate assistants were offered. This fall, three sections will be offered. She has changed the grading procedures somewhat over time, added new Websites and readings, and revised the instructions to students. This fall a major change to one of the modules and the addition of overview sections to each will be added.

Media in Teaching and Learning (ETAP 523) was developed by both Meskill and Professor Swan. They co-taught it the first semester. Professor Swan has taught it once on-line and once face-to-face since then. Although she added a journaling activity and made major changes to the computing module in ETAP 523, it is interesting to note that she made more changes in her face-to-face teaching based on the on-line version of the course.

Professor Swan has only taught Mass Media and Education one time on-line, but its development (as previously noted) was highly influenced by her experiences with the other two courses. In particular, she based the course mainly on the discussion of a series of (sometimes provocative) readings, and trusted students to collectively construct meaning through this means. The only changes she anticipates making in this course are perhaps in the readings. 


\begin{tabular}{|c|c|c|c|c|c|}
\hline & TELECOM & TUTOR & TOOL & TUTEE & \\
\hline READINGS & $\begin{array}{l}\text { critique \& summary } \\
\text { ( } 2 \text { points) }\end{array}$ & $\begin{array}{l}\text { critique \& summary } \\
(2 \text { points })\end{array}$ & $\begin{array}{l}\text { critique \& summary } \\
(2 \text { points) }\end{array}$ & $\begin{array}{l}\text { critique \& summary } \\
\text { ( } 2 \text { points) }\end{array}$ & 8 points \\
\hline PRACTICUM & $\begin{array}{l}\text { email ( } 3 \text { pts) } \\
\text { eval criteria ( } 3 \text { pts) } \\
\text { web sites }(3 \text { pts })\end{array}$ & $\begin{array}{l}5 \text { software reviews } \\
\text { (X } 2 \text { pts each } \\
=10 \text { points) }\end{array}$ & $\begin{array}{l}\text { wordprocess ( } 3 \text { pts) } \\
\text { data manip ( } 3 \text { pts) } \\
\text { presentation (3 pts) }\end{array}$ & $\begin{array}{l}\text { Logo I (4 pts) } \\
\text { Logo II (4 pts) } \\
\text { (or prog. evidence, } 8 \\
\text { pts) }\end{array}$ & 36 points \\
\hline PROJECT & $\begin{array}{l}\text { lesson plan } \\
(4 \text { points })\end{array}$ & $\begin{array}{l}\text { lesson plan } \\
(4 \text { points })\end{array}$ & $\begin{array}{l}\text { lesson plan } \\
(4 \text { points })\end{array}$ & $\begin{array}{l}\text { lesson plan } \\
(4 \text { points })\end{array}$ & 16 points \\
\hline DISCUSSION & $\begin{array}{l}3 \text { postings } \\
+3 \text { comments } \\
(\mathrm{X} 1 \mathrm{pt} . \text { each } \\
=6 \text { points }) \\
\end{array}$ & $\begin{array}{l}3 \text { postings } \\
+3 \text { comments } \\
\text { (X } 1 \text { pt. each } \\
=6 \text { points) }\end{array}$ & $\begin{array}{l}3 \text { postings } \\
+3 \text { comments } \\
\text { (X } 1 \text { pt. Each } \\
=6 \text { points) }\end{array}$ & $\begin{array}{l}3 \text { postings } \\
+3 \text { comments } \\
(\mathrm{X} 1 \mathrm{pt} . \text { Each } \\
=6 \text { points })\end{array}$ & 24 points \\
\hline \multirow[t]{2}{*}{ REFLECTION } & $\begin{array}{l}3 \text { postings } \\
\text { (X 1pt. Each } \\
=3 \text { points) }\end{array}$ & $\begin{array}{l}3 \text { postings } \\
\text { (X 1pt. each } \\
=3 \text { points) } \\
\end{array}$ & $\begin{array}{l}3 \text { postings } \\
\text { (X 1pt. each } \\
=3 \text { points) }\end{array}$ & $\begin{array}{l}3 \text { postings } \\
\text { (X 1pt. each } \\
=3 \text { points) } \\
\end{array}$ & 12 points \\
\hline & 24 points & 25 points & 24 points & 23 points & 96 points \\
\hline
\end{tabular}

Figure 5

Portfolio Assessment for ETAP 426/526 (Computing in Education)

MODULES

\begin{tabular}{|l|c|c|c|c|c|c|c|}
\hline & Introduction & Mass Com. Soc. Reality & News \& Info. & Consumerism & Media Lit. & \\
\hline $\begin{array}{l}4 \text { disc. postings } \\
\text { @ } 1 \text { pt. ea. }\end{array}$ & 4 & 4 & 4 & 4 & 4 & 4 \\
\hline $\begin{array}{l}\text { c disc. } \\
\text { comments } \\
\text { a } 1 / 2 \text { pt ea. }\end{array}$ & 2 & 2 & 2 & 2 & 2 & 2 & 12 \\
\hline $\begin{array}{l}1 \text { construction } \\
\text { @ } 4 \text { pts. }\end{array}$ & $\begin{array}{c}\text { (media log) } \\
4\end{array}$ & $\begin{array}{c}\text { (analyses) } \\
4\end{array}$ & $\begin{array}{c}\text { (TV critique) } \\
\text { (news comp.) } \\
\text { (posit. paper) }\end{array}$ & $\begin{array}{c}\text { (lesson plan) } \\
4\end{array}$ & 24 \\
\hline $\begin{array}{l}2 \text { const. } \\
\text { comments } \\
\text { @ } 1 / 2 \text { pt ea. }\end{array}$ & 10 & 11 & 11 & 11 & 1 & 1 & 5 \\
\hline
\end{tabular}

MEDIA OBSERVATIONS

\begin{tabular}{|l|l|l|l|l|l|l|l|l|l|l|l|l|l|l|l|}
\hline & $\# \mathbf{1}$ & $\mathbf{\# 2}$ & $\mathbf{\# 3}$ & $\mathbf{\# 4}$ & $\mathbf{\# 5}$ & $\mathbf{\# 6}$ & $\mathbf{\# 7}$ & $\mathbf{\# 8}$ & $\mathbf{\# 9}$ & $\mathbf{\# 1 0}$ & $\mathbf{\# 1 1}$ & $\mathbf{\# 1 2}$ & \\
\hline $\begin{array}{l}\text { 1 obsrv. @ } \\
\mathbf{2} \text { pts }\end{array}$ & 2 & 2 & 2 & 2 & 2 & 2 & 2 & 2 & 2 & 2 & 2 & 2 & 24 \\
\hline $\begin{array}{l}\mathbf{2} \text { comments } \\
\text { @ } \mathbf{1 / 2} \text { pt ea. }\end{array}$ & 1 & 1 & 1 & 1 & 1 & 1 & 1 & 1 & 1 & 1 & 1 & 1 & 12 \\
\hline & 3 & 3 & 3 & 3 & 3 & 3 & 3 & 3 & 3 & 3 & 3 & 3 & $\mathbf{3 6}$ \\
\hline
\end{tabular}

TOTAL POSSIBLE POINTS $=101$

Figure 6

Portfolio Assessment for ETAP 522 (Mass Media and Education) 


\section{RESULTS}

For the first two semesters in SLN, faculty used on-line versions of the standard student evaluations usually given at the end of the semester. These Likert-type rankings ask students to agree or disagree (on a five-point scale with five representing strongly agree) with two statements-This course was excellent and This instructor was excellent. The evaluations are traditionally given with the instructor absent from the room. They are machine scored and give a total (averaged) rating for each course. The on-line versions were E-mailed to students and compiled by the SLN staff.

A comparison of evaluations for two courses for which this was done is given in Figures 7 and 8. The comparison is between student evaluations of the on-line versions of each course and student evaluations of the traditional version of the same course given in the preceding year. Student evaluations of the on-line versions of these courses were slightly higher but statistically similar to student evaluations of their traditional versions.
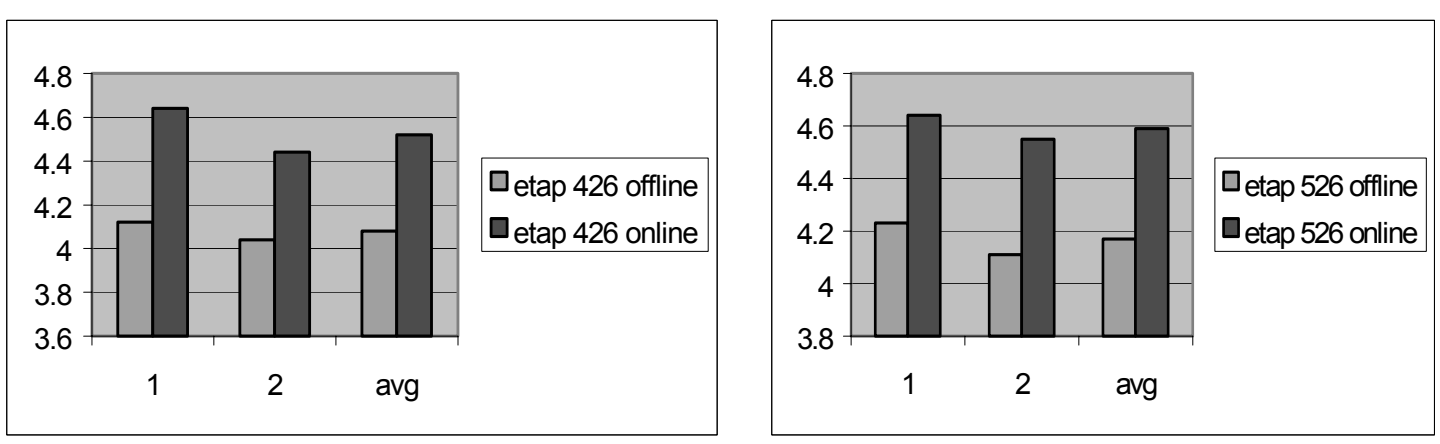

Figure 7

Comparison of Student Rankings for Traditional vs. On-line Versions of ETAP 426/526

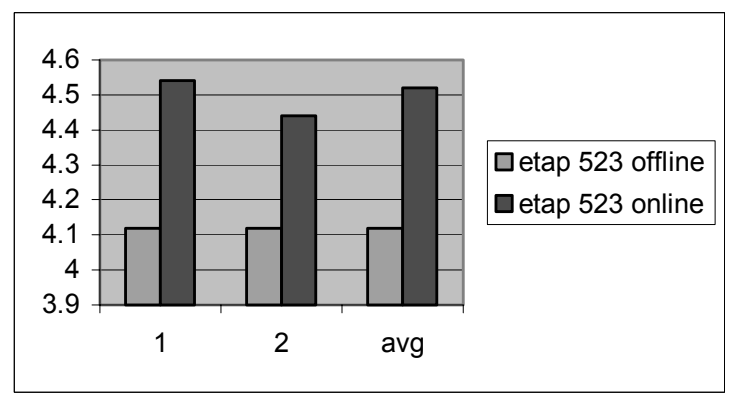

Figure 8

Comparison of Student Rankings for Traditional vs. On-line Versions of ETAP 523

The faculty in the department has been extremely satisfied with the experience of on-line teaching. Several have decided to only offer certain courses on-line. All the faculty who created on-line courses continue to teach them, although they are not required to do so. The enthusiasm for the SLN program remains high, and faculty are becoming advocates for it both on campus and throughout the SUNY system.

Professor Swan personally believes the reason for these high levels of faculty satisfaction is the way SLN has valued faculty from the very beginning. Faculty own the courses and have the final say in their development. SLN has never sought to replace or automate faculty. Indeed, the SLN administrators and staff have consistently made teaching and teachers a priority. The MIDs assigned to all faculty members are instructional designers first, 


\section{AND LEARNING}

technical assistants second. The Help Desk staff are available at all hours, seven days a week to help with technical problems.

The next section provides results of data collected on faculty satisfaction in the Internet Academy (IA) of Herkimer County Community College (HCCC). This program represents an innovative local initiative for the delivery of courses in conjunction with SLN.

\section{FACULTY SATISFACTION AT THE HERKIMER COUNTY COMMUNITY COLLEGE INTERNET ACADEMY}

\section{INTRODUCTION}

This section will deal with the sequence of events leading to the formation of the IA at HCCC. HCCC is a medium sized (2,500 students) two-year college in upstate New York. In spring 1997, HCCC decided to join several other SUNY colleges and participate in the SLN. The academic dean decided that HCCC would begin by offering Internet-based courses leading to the A.A.S. degree in Travel and Tourism, a program that HCCC has offered with great success for many years. In preparation for the fall, 1997 semester, three courses were selected, three faculty members were recruited, and a campus-support person was designated.

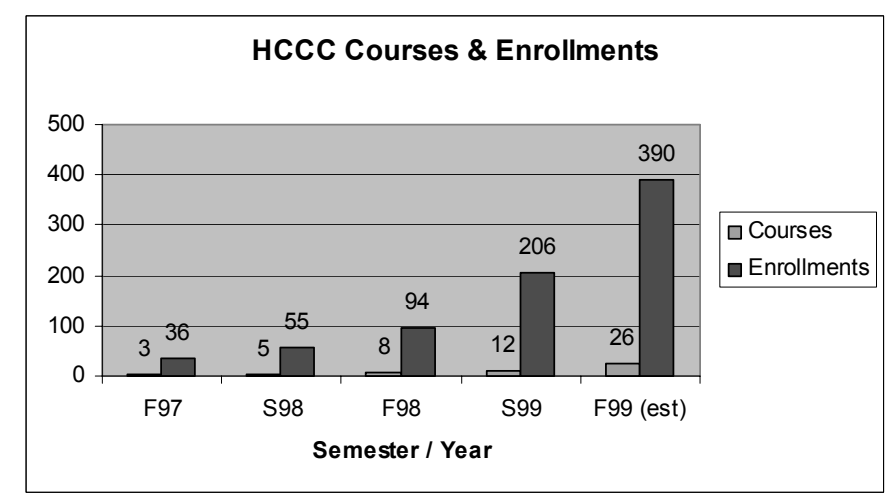

Figure 1

As seen in Figure 1, the total fall 1997 enrollment was 36 students. In spring 1998 five SLN courses were offered with a total enrollment of 55. In the fall 1998 semester we offered eight courses to 94 students; and in spring 1999 there were 12 courses with 206 students. HCCC will offer 26 courses in fall 1999, and anticipates approximately 390 students.

During spring 1999, plans were made to expand the Internet-based courses into additional programs, and the IA grew out of this effort. The IA was inaugurated at a press conference on May 6, 1999. Students are currently able to get admitted to the college, register for courses, and complete all of the coursework in any one of six degree programs, all without visiting the campus. Plans are to expand this to ten degree programs in fall 2000 . Each program requires between 62 and 65 credits to complete. Course offerings will be programmed in such a way that a student may complete a degree program within two years. The college maintains an IA Website at http://hccc.ntcnet.com/IA.

\section{RATIONALE}

The IA is thought of as a separate entity within the college. Although the Internet-based courses are scheduled concurrent with the on-campus course calendar, they are intended to appeal to students who find it difficult or impossible to travel to campus for their coursework. Participants in our Internet-based courses completed a survey during the spring 1999 semester. The data suggests that approximately $40 \%$ would not be able to take the courses if 
they were required to attend classes on campus. Additionally, data suggests that the most important reason why students take Internet-based courses is for convenience.

Prior to fall 1997, there was no Internet-based instruction at HCCC. In fact, the Internet first became available on campus in the fall 1996. The individual who was designated as the support person for the SLN courses had been appointed director of learning systems technology (LST) in fall 1997, and was primarily concerned with two-way compressed video as the means of providing distant access to campus courses. Then in spring 1999, at an all-faculty meeting, the president of HCCC, Dr. Ron Williams, suggested that we should begin thinking more globally about our Internet-based courses. He went so far as to proclaim his interest in creating "some kind of Internet Academy" with the goal of providing easy access to our programs for disabled and non-traditional learners. A short time later the director of LST expressed an interest to Dr. Williams in pursuing the idea of an IA, and, with a tremendous amount of campus-wide cooperation and support, the IA now exists.

HCCC has encouraged and facilitated involvement by full-time faculty in Internet-based instruction by providing a budget which addresses faculty needs. When a professor volunteers to develop an Internet-based course, and this is never required, they are provided with a computer and printer for home - even if they already have a home system. In addition, they receive a stipend (approximately $\$ 1,000$, dependent upon academic rank) for developing and teaching the course. Also, the college pays to have a second telephone line (or Road Runner) installed into the professor's house (up to $\$ 200$ ), and pays up to $\$ 40$ per month for telephone and/or Internet access. This year, the college also moved to provide a local campus MID. Faculty travel expenses to SLN workshops are also provided. In exchange, faculty agree to teach each course they develop a minimum of two times.

It is the goal of the college to have all of the Internet-based courses taught by current or retired HCCC professors. That goal, so far, has been mostly successful. Two adjunct professors have been utilized to develop and teach courses they were already teaching in the classroom. Presently, all other Internet-based courses are being taught by active or recently retired full-time faculty. All current faculty teaching Internet-based courses have at least 15 years of college classroom teaching experience; three are recipients of the Chancellor's Award for excellence in teaching.

\section{METHOD}

For the method section, this case study will focus on the professor at HCCC with the greatest amount of Internet teaching experience. Professor William Pelz, the author of this section, taught two courses, Freshman Seminar (one credit) and Introductory Psychology (three credits) in the fall 1997 semester using courseware called TopClass. The courses were not offered via the SLN, but were hosted by SUNY on a SUNY server as part of a university-wide evaluation of TopClass. Introductory Psychology has subsequently been taught four times via the SLN using Lotus Notes, and the Freshman Seminar has been taught two more times, also using Notes. In addition, Professor Pelz has developed and taught Abnormal Psychology (twice) and Social Psychology (once). In addition to teaching over the Internet, Professor Pelz has taught Introductory Psychology and Social Psychology over a two-way compressed video interactive synchronous network. Because of these experiences he is well positioned to offer opinions concerning courseware, technology and pedagogical issues.

\section{A. Technology and Infrastructure}

The courses were developed using either TopClass (1997) or Lotus Notes-with custom templates provided by SLN-(1997-present). Of the two course-management programs, Lotus Notes was the more mature product and provided the most satisfying experience for both the students and the professor. To a large extent, the ease of use and pedagogical functionality of Lotus Notes is provided through the custom templates developed by SLN programmers. These templates enable the use of class discussions, small group exercises, self-tests and assignments with relative ease, and are flexible enough to allow each professor to exhibit his/her own style of interaction. Although the SLN courses are developed with Lotus Notes, they are viewed by students using their Web browsers. No special software is required. The SLN templates provide a consistent look and feel to all of the courses, making the students task of mastering the technology much easier. 
The infrastructure of servers is provided by SLN. Several servers (the number has grown over the years to five) are maintained and all of the course databases are replicated among these servers frequently. This system provides a great amount of redundancy, so that equipment failures almost never prohibit access to the courses. In addition to servers, SLN provides extensive training and support, both during course development and course administration. There has been no charge for these infrastructure services to date, but that looms as a future possibility.

\section{B. Course Delivery}

For all of the courses personally developed by Professor Pelz, the pace is determined by him, not the student. The primary reason for this is to facilitate the discussions of course-related topics and to involve every student in these discussions. In contrast to Professor Swan's experiences in the classroom, he has found that most students are willing, many even eager, to discuss relevant, course-related topics asynchronously. The pedagogy he uses requires each student to lead discussions on topics they select from the readings. The other students in the class are required to participate in these discussions by responding to critical thinking questions posed by the student discussion leaders. He permits each discussion to continue until it self-extinguishes, and he interjects comments only as needed to facilitate the integrity and accuracy of the discussion. He attributes much of the student excitement and enthusiasm for his courses to this strategy. Additional on-line activities include essay exams on the readings (which he treats as take-home, open-book exams) and Web-based research papers, which require students to locate and sift through the content of numerous Web sites and make decisions on the value of the information they convey.

Student performance is assessed as follows: participation in discussions (quality of questions and responses as well as quantity of contributions) $-50 \%$; essay exams on the content $-20 \%$; and research papers $-30 \%$. There are no synchronous activities required.

\section{Organization and Evolution}

Course development is the responsibility of the professor. However, there is bountiful support from the SLN staff, and more recently from local campus expertise. The SLN staff conduct a series of workshops which new course developers are required to attend. In addition, there are separate workshops which experienced Web-instruction faculty are encouraged to attend. There are three workshops for new faculty. They are conducted throughout New York State at sites convenient for all participants. The training begins about six months prior to the course going live and continues until the course begins. Support is not limited to the workshops. Each professor is assigned a MID who works with him/her on a one-to-one basis throughout the development cycle. Initially, MIDs who work for SLN provide this service. But as campus participation grows, the campus is expected to provide this support locally. As an example, HCCC appointed Professor Pelz as campus MID when it was decided to launch the IA. It is expected that each campus will do this when the number of courses they offer reaches 15-20 per semester.

Additional support is provided by the SLN Help Desk. At any time, a faculty member can call or E-mail the Help Desk to receive assistance in using the technology such as server access, modem setup, E-mail and file attachment issues etc. And this same Help Desk support is available to students in the courses.

A final support exists in the form of a Developer's Handbook. This reference provides step by step instructions and examples of the tasks required to develop and manage a course using Lotus Notes and the SLN templates. The Developer's Handbook is periodically updated and is indexed for ease of use.

A faculty satisfaction survey was administered to spring 1999 Internet-based course professors. Six of the eight professors responded to the survey. All of the professors had at least 15 years of classroom-based teaching experience, four had in excess of 20 years experience. These six professors have developed and taught a total of 15 Internet-based courses. None had any experience with asynchronous learning prior to their involvement in this project. All of the faculty surveyed have taught their course(s) at least twice on-line; and half of them have taught their on-line course(s) four times. 


\section{RESULTS}

The faculty satisfaction survey revealed a number of indicators that address the issue of teaching satisfaction. Eighty-three percent responded that they found their on-line teaching experiences very satisfying and $17 \%$ found them somewhat satisfying. One-hundred percent of the faculty responded that they plan to continue teaching on-line courses. Eighty-three noted that developing an on-line course had a very positive impact on their classroom teaching. They made the following comments:

- "I facilitate more and better classroom discussions. Also, I give more WWW-based research projects."

- "It has impacted the classroom experience by turning it into a more active learning environment. Students are challenged with tasks that must be completed using their own creativity and resourcefulness."

- "The discussion on-line is more passionate and vibrant. I have learned some 'hot buttons' that will touch-off great discussions."

- "Does not apply because I have not taught this course (EN 236) on campus recently. I have used some of the on-line strategies prior of teaching SLN course-so I checked them below."

Asked to evaluate the effectiveness of the on-line teaching strategies they used, $83 \%$ responded that they were very satisfied. Sixty-seven percent of the faculty characterized the quantity of student-to-student interaction, and studentto-professor interaction as "more than in the classroom". In response to a question about the quality of interaction, $67 \%$ said that the quality of student-to student interaction was higher than in the classroom, and $50 \%$ responded that the quality of student-to-professor interaction was higher than in the classroom.

When asked why some mainstream faculty might resist on-line teaching, they gave the following responses:

- Afraid of the technology. Unsure of the pedagogy. Question the authenticity. Cannot be sure who is answering the questions.

- Because they are afraid of the unknown and the potential work involved in trying something new.

- It threatens the territory they have become comfortable in.

- Technophobia and not having done thorough research or having had exposure to the methodology.

- They believe on-line teaching is too impersonal-does not allow for meaningful interaction-they are wrong.

Asked what could be done to break down this resistance, they replied:

- Demonstrate effective pedagogy. Testimonials from respected colleagues. Roundtable discussions with experienced on-liners.

- Set a good example and outline the positive features about teaching over the Internet.

- Convince them it's not a threat, just an enhancement.

- Professional development seminars where faculty are interactive within a course for a period of a week or two.

- Have one-on-one demonstrations with faculty who are cautiously suspicious, but who have some possibilities. Show them a course and answer their questions. Suggest that they take a course on-line themselves before teaching one. It could be simply auditing someone's course.

\section{ABOUT THE AUTHORS}

Eric E. Fredericksen is the Assistant Provost for Advanced Learning Technology and a senior manager in Advanced Learning \& Information Services, part of the Office of the Provost in the State University of New York System Administration. He is a member of the AL\&IS Leadership Group and provides leadership and direction for 
all of SUNY's system-wide programs focused on the innovative use of technology to support the teaching and learning environment. This includes the SUNY Learning Network - the SUNY System's premiere asynchronous learning program.

Fredericksen is also the Co-Principal Investigator and Administrative Officer for a multi-year, multi-million dollar grant on Asynchronous Learning Networks from the Alfred P. Sloan Foundation. He is responsible for the fiscal management, strategic planning, policy development, faculty development, marketing \& promotion, student support center, and technical infrastructure. Under his leadership the program has grown from 2 campuses offering 8 courses to 119 enrollments to 42 campuses offering 1000 courses to over 13,000 enrollments in just four years.

Fredericksen received his bachelor's degree in Mathematics from Hobart College, his M.B.A. from the William Simon Graduate School of Business at the University of Rochester and his Master of Science in Education in Curriculum Development \& Instructional Technology at the Graduate School of Education at the University at Albany.

Contact: SUNY Learning Network, The State University of New York, SUNY Plaza, N 303, Albany, New York 12246; Telephone: 518-443-5331; Fax: 518-443-5167; E-mail: efrederi@sln.suny.edu.

Alexandra M. Pickett is the Assistant Director of the SUNY Learning Network (SLN), the Asynchronous Learning Network for the State University of New York under the offices of the Provost and Advanced Learning and Information Services. A pioneer in instructional design and faculty development for asynchronous teaching and learning environments, Pickett has since 1994 led the development of the instructional design methods, support services, and resources used by SLN to develop and deliver full web on-line courses. She has spent the past six years conceptualizing and implementing scaleable, replicable, and sustainable institutionalized faculty development and course design and delivery processes that in the 1999-2000 academic year resulted in the delivery of close to 1000 courses with 13,000 student enrollments. One of the original SLN design team members, she co-designed the course management software and authored the 4-stage faculty-development process and seven step course design process used by the network. Her comprehensive approach includes an on-line faculty resource and information gateway, an on-line conference for all faculty with the opportunity to observe a wide variety of on-line courses, a series of workshops for new faculty, instructional design sessions for returning faculty looking to improve their courses, a developer's handbook, a course template, a faculty Help Desk, on-line mechanisms for faculty evaluation of SLN services, and an assigned instructional design partner. Today, working with 47 of the 64 SUNY institutions, she has directly supported or coordinated the development of more than 600 SUNY faculty and their web-delivered courses. Her research interests are in faculty satisfaction and the effective instructional design of on-line courses, and student satisfaction and perceived learning. She has co-authored a number of studies on these topics and has published and presented the results both nationally and internationally.

Contact: SUNY Learning Network, The State University of New York, SUNY Plaza, N 303, Albany, New York 12246; Telephone: 518-443-5331; Fax: 518-443-5167; E-mail: apickett@SLN.suny.edu; URL: http://SLN.suny.edu/developer.

William Pelz is Professor of Psychology and Coordinator of the HCCC Internet Academy at Herkimer County Community College. Professor Pelz joined the faculty of HCCC in August of 1968, the second year the college was in operation. During his 32 year tenure at HCCC he has served as Chair of the Humanities and Social Science Division and Director of Distance Learning, but has always returned to his first love-teaching. In 1994 he was presented with the SUNY Chancellor's Award for Excellence in Teaching-his most cherished prize. Bill has published an eclectic assortment of scholarly and academic articles, most recently focused on the area of asynchronous teaching and learning. He is a vocal advocate for ALNs, and provides training for faculty throughout New York State for the SUNY Learning Network. 
Contact: Herkimer County Community College, 100 Reservoir Road, Herkimer, New York 13350; Telephone: 315866-0300, ext. 211; Fax: 315-866-0402; E-mail: pelzwe@hccc.suny.edu.

Karen Swan is Associate Professor of Instructional Technology at the University at Albany Graduate School of Education where she is also Director of the Learning Technologies Laboratory and the Summer Technology Institutes. Dr. Swan's research has been focused mainly in the general area of computers and education. She has published and presented both nationally and internationally in the specific areas of programming and problem solving, computer-assisted instruction, hypermedia design, multimedia, and asynchronous on-line learning. Her current research focuses on the latter, and on changing notions of literacy for the Information Age. She has also written on social learning from broadcast television, about which she co-edited a recently published book. Dr. Swan has authored several hypermedia programs including Set On Freedom: The American Civil Rights Experience for Glencoe and The Multimedia Sampler for IBM, as well as three on-line courses which are being offered through the SUNY Learning Network, which she has taught for the past two years. She is a project director in the Technology and Literate Thinking Strand of the National Research Center on English Learning and Achievement (CELA) and is currently working on formative and usability evaluation for Project Links at RPI. Dr. Swan serves on the program committees for several local and international instructional technology conferences and is the Special Issues Editor for the Journal of Educational Computing Research.

Contact: SUNY Albany, 1400 Washington Avenue, ED 114A, Albany, New York 12222; Telephone: 518-4425032; Fax: 518- 442-5008; E-mail: kswan@uamail.albany.edu.

Peter Shea is the Course Management Systems Manager for the 64 campuses of the State University of New York. Formerly Lead Instructional Designer for the SUNY Learning Network (SLN) he has assisted in the design of more than 100 on-line courses and provides training in on-line pedagogy to new instructional designers for SLN. His research interests include student satisfaction and learning in internet-based distributed education and he has published a number of studies on this topic. He has also published and presented the results of research on computer assisted learning both nationally and internationally. Dr. Shea also teaches part-time in the department of Educational Theory and Practice at the University at Albany, State University of New York.

Contact: The State University of New York, SUNY Plaza, N 303, Albany, New York 12246; Telephone: 518-4435331; Fax: 518-443-5167; E-mail: pshea@sln.suny.edu. 



\title{
Factors Influencing Faculty Satisfaction with Asynchronous Teaching and Learning in the SUNY Learning Network
}

\author{
Eric Frekericksen, William Pelz, Alexandra Pickett, Karen Swan, Peter Shea
}

\section{Discussant: Richard Crang, University of Illinois at Urbana-Champaign}

The concept of the University as a corporation is not a new one except, perhaps, to a few isolated faculty who may still suffer from the mistaken belief that we are, somehow in a classical academia, where we are still free to pursue our research and teaching as we see fit. But as most of us realize, the corporate university is a reality, and one with which we need to understand and work. And any corporation that is viable must develop a marketing plan for their products; they must have a plan to meet consumer needs, they must be able to provide a direct and cost-efficient means of getting their products to market, and they must be able to recognize the devoted efforts of their employees who have invented the products and those who have sold and supported them. I would say that the SUNY Learning Network (or SLN) has put this concept into practice in a most remarkable manner. In a very short period of time they have set into place a formula for producing and delivering their on-line courses efficiently and effectively, increasing the numbers of courses and their combined enrollments by two orders of magnitude within four years. The SUNY group has defined their efforts at all levels - ranging from the program level to the level of specific institutions and courses.

During this meeting, we have heard that small institutions may not have the resources or, in some cases, even a plan, for such level of activity. Yet plans as developed by SUNY can be replicated functionally on different scales-both up and down. Look at some of the key component parts: faculty training, collaborative experiences, use of common templates, support staff-ingredients designed to make the plan work. These ingredients that give the faculty direction and confidence in what they are doing, and that leads to faculty satisfaction.

For after all, faculty members largely tend to be a very insecure species, and have a great many fears with which to contend. To name a few: fear of not getting tenure, fear of lack of professional recognition, fear of no advancement, fear of not getting to teach their specialty, fear of getting to teach their specialty in addition to others, fear of unionization, or perhaps fear of not being unionized. It is therefore natural that faculty can have a fear of entering into a new modality of instruction - the time and effort it is likely to take, developing mastery of the technology, and creating an effective instructional persona that augments or replaces their face-to-face experiences. SUNY has recognized this and has devoted a very large share of their resources to overcoming such faculty fears and concerns, using a standardized model that works. And this leads to faculty satisfaction overall as indicated in the range of experiences from the University at Albany to Herkimer County Community College. Satisfaction is measured by student performance, student interaction, the SLN Program itself, the level of technology, and faculty knowledge of their students.

One may criticize the SLN for not having a wide range of course delivery options available, not using CourseInfo (Blackboard), WebCT, WebBoard or other means of delivery aside from that provided by their Lotus Domino servers. But the SUNY delivery system does not preclude the use of CD-ROMs, texts, videos, and other media, as well as non-technological activities for course delivery. The core of the SLN may be, as Alexandra Pickett has described, a "vanilla" delivery; but vanilla is most palatable. It also allows for a great many toppings and, most importantly, the SUNY vanilla does the job for students with varied levels of accessibility. 
I am led to believe that the SLN has another possibility that has yet to reach its potential. Due to the unifying nature of the SLN system throughout the SUNY campuses, the stage is set for individual courses and programs to be jointly offered from multiple campuses as well as to multiple campuses and beyond.

Finally, some of us have been around long enough to have pondered the question posed by George Axelrod: "Will Success Spoil Rock Hunter?" We might well wonder from the enormous growth that has occurred, and which potentially will take place in the SLN, if success by such measure can be maintained, and if it will spoil the progress made and faculty satisfaction with teaching on-line. And, like Rock Hunter, will universities get in over their heads to save their accounts? It would appear that sustainability of instructional quality and faculty satisfaction will require both continued innovative uses of technology, and the financial resources necessary to cope with success. SUNY, like so many academic institutions, has been meeting the challenge, but the challenge is not over.

\section{ABOUT THE DISCUSSANT}

Richard Crang is Professor of Plant Biology at the University of Illinois at Urbana-Champaign (UIUC) and, for the past two years, has been a faculty fellow in conjunction with the U of I Online Office working with the UIC Health Professions on-line course initiative at Chicago. He has developed on-line courses in plant biology at UIUC.

Contact: Department of Plant Biology, University of Illinois at Urbana-Champaign, 265 Morrill Hall

505 South Goodwin Avenue, Urbana, Illinois 61801; Telephone: 217-333-0616; Fax: 217-244-7246; E-mail: r-crang@life.uiuc.edu. 